\title{
横断の歴史的使命
}

\section{吉川 弘之*}

日本学術会議は科学者を代表するものであるが，こ の場合の科学者は70万人いるとされている。それは日 本学術会議の 210 名が選び出される母体としての学協会 で研究を行っているものの数である。選出は学協会の 推萀を基本としているのであるが,それに関与する「登 録学術研究団体」は1,400に及ぶ.70万人が1,4000学 会に属しているのだから平均500名であり，それに対応 して登録団体となるために, 人文社会系で 100 人, 農 200 人, 理 300 人, 工. - 医500人が最低構成人数として定め られている。日本爫術会議の会員となって改めてこの 数を見たとき，私は少なからず衝撃を受けた。登録さ れている学会の数(1997年当時で1221)があまりに多い. そして学会の構成員があまりに少ない，学会というの は，学問領域に対応するもののはずであるから，この ように多数の「領域」が存在することに驚かされたの である、学閆が社会的に機能を求められている時代に, 細分化された領域はそれぞれどんな機能を持ち得るの であろうか.とくに現代において学問が必要となる課 題は複雑で統合的である。私はそこで，「俯瞰的視点」 の重要性を主張せざるを得なかった。宰い俯瞰的視点 という考之方は日本学術会議で受け入れられ，一般社 会でも広く使われるようになった。しかし，この視点 をどのように作り出すかについては，未だ十分な方法 があるわけではない。この時期に，計測自動制御学会 などが中心となって「横断型基幹科学」を提案したこ とはまことに時宜を得たものであり，大きな発展が期 街される。

ところで学会は何故このように細分化されるのであ ろうか. 会員数が数百人では，そこでの関心事は特定 の研究課題か，一つの学説なのではないかと考えられ る。学閣領域というのは，それ以上抽象化されると意 味を失うまで十分抽象化された概念によって，できる だけ多くの個別事象を包含し，しかも抽象化によって それらの事象が共通の方法で取り扱われるようになつ たものであり，包含される個別事象が多ければ多いほ ど，その領域の価値が高い。従って，抽象化によって

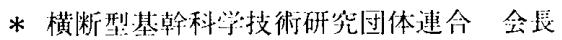

* 独计行政法人座業技術総命研究诿理事长

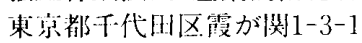

起きてしまう意味の整失の阻止と, 包含する事象の数 の最大化との均衡において領域は辛うじて成站するも ののはずである.1，4000学会が，その苦しみの中にあ るかどうかは別として, 細分化の歴史を考えてみよう。

学間のはじまりは分類である，と言われることがあ る. 確かに学問は対象を理解することを一つの条件と しているから，異なる対象を区別することはその基本 である。そして，その分類の視点によって独自の分類 の体系ができ，それは独自の領域と言ってよい. 代表 的なのはアリストテレスの動植物の分類であるが, 視 点を明確に定めることによって成功したのがリンネの 植物分類学である。成功というのは，リンネがすべて の植物を包含し，分類を厳密に階層化して示すことに より，抽象的な体系を作り得たからである.しかしこ の場合，最も抽象的な類は「植物」ということになっ て意味は空白となってしまい，そこから具体的な植物 を生み出すことはできない、アリストテレスを批判す るカッシーラーは, 直観による抽象は不毛であるとし, 数や空間概念などに導かれてする抽象が現在の学問領 域を生むと言う。運動の抽象によって二次方程式を得 れば,パラメータの変更によって阿や譛邖が得られる。 阿や楕四は，具体的な運動である。

学閏領域というのは, 前述のように抽象化によって 普遍的理解を生む方法を持っているが，その理解の結 果, 再び具体的なものへ「帰って」行けるかどうかが 問題である.カッシーラ一の指摘はその意味で重要で あるが, 彼の例は楽観的過ぎる. 多くの学問的研究に よって，私たちは具体的なものを哚く理解するように なった。それは非裳に多くの法則を手にしたことを意 味している。しかし，これらの法則から必要なものを 選び，再び具体的なものへ帰って行く道筋を私なちは 知らない。 その理由は，力ッシーラーが考えていたの は同じ領域へ帰ることだったのだが，実は彼が考えて いたよりも遙かに多くの領域が生み出されたのであり, しかも当然のこととして，帰るべき現実とは多くの領 域にまたがって存在しているものであり，四や棈刉は その意味では現实ではなく，領域内に止まる依然とし て抽象度の高い要素に過ぎないということになるであ ろう。科学者たちは長い間このことを考えて来た。 た 
とえば国際科学会議(ICSU)が、既に1931年に学問領域 の交流をその最重要な目的として設站されたのである。 学開領域の細分化は, 避けられない傾向であり, 従っ てそれに対応する方法を常に案出し続ける必要がある。
横断型基幹科学は，その意味で歴史的な使命を持つも のと考えるべきである.

(「棓測と制御」Vol.42，No.5 から転載（許諾済み）） 